\title{
ANALISIS PRAKTEK KEPERAWATAN MEDIKAL BEDAH DENGAN PENDEKATAN TEORI ADAPTASI ROY PADA PASIEN GANGGUAN PERSYARAFAN DI RSUPN DR. CIPTO MANGUNKUSUMO JAKARTA
}

\author{
Pujiarto \\ Akper Panca Bhakti Bandar Lampung \\ Email: pujiart_77@yahoo.com
}

\begin{abstract}
Analysis of Nursing Practice Medical Surgery with Approach to The Theory of Roy's Adaptation in Neurological Disorders Patient in RSUPN dr. Cipto Mangunkusumo Jakarta. Methods that used in Medical surgical nursing practice were the case study design. It was done by implement nursing care in patients with impaired neurological using Roy's adaptation model. Cerebral tissue perfusion disturbances, impaired physical mobility, and self-care deficit were problem of nursing that commonly happen in patients with neurological disorders. Nursing interventions were needed to aim to address those nursing issues. Application of the theory adaptation Roy were very appropriate in patients with impaired neurology, because it is one theory that is dynamic and focused on adaptability of patients and included theory easily applied in the implementation of nursing care. Roy asserts that the individual is a biopsychosocial beings as a unified whole that have the coping mechanisms to environmental changes in order to achieve an adaptive condition.
\end{abstract}

Keywords: Medical surgery, Ischemic stroke, Roy adaptation model

\begin{abstract}
Abstrak: Analisis Praktek Keperawatan Medikal Bedah dengan Pendekatan Teori Adaptasi Roy pada Pasien Gangguan Persyarafan di RSUPN Dr. Cipto Mangunkusumo Jakarta. Metode yang digunakan padaPraktek keperawatan medikal bedah ini menggunakan desain studi kasus yaitu dengan melaksanakan asuhan keperawatan pada pasien dengan gangguan persyarafan menggunakan model adaptasi Roy. Masalah keperawatan yang umumnya terjadi pada pasien dengan gangguan neurologis diantaranya gangguan perfusi jaringan serebral, gangguan mobilitas fisik, dan defisit perawatan diri.Kemudian menyusun intervensi keperawatan yang bertujuan untuk mengatasi masalah keperawatan tersebut. Hasil penerapan teori adaptasi menurut Roy sangat tepat pada pasien dengan gangguan persyarafan karena merupakan salah satu teori yang dinamis dan berfokus pada kemampuan adaptasi pasien dan termasuk teori yang mudah diaplikasikan, dalam penerapan asuhan Keperawatan. Roy menegaskan bahwa individu adalah makhluk biopsikososial sebagai satu kesatuan utuh yang memiliki mekanisme koping terhadap perubahan lingkungan untuk mencapai kondisi adaptif.
\end{abstract}

Kata kunci: Medikal bedah, Stroke iskemik, Model adaptasi Roy

Pelayanan keperawatan merupakan seni melayani/merawat (care), yang bersifat humanistik dari ilmu pengetahuan keperawatan (teori keperawatan), filosofi keperawatan, kegiatan klinik, komunikasi, dan ilmu sosial (World Health Organization (WHO) Expert Committee on Nursing (1982, dalam Aditama, 2000). Keperawatan adalah suatu bentuk pelayanan profesional yang didasarkan pada ilmu dan kiat keperawatan, berbentuk pelayanan bio, psiko, sosial, dan spiritual yang ditujukan kepada individu, keluarga, dan masyarakat yang sehat maupun sakit mencakup seluruh proses kehidupan manusia (lokakarya keperawatan nasional, 1983 dalam Gaffar, 1999). Marquis (2000), menyebutkan pelayanan keperawatan yang profesional merupakan praktik keperawatan yang dilandasi oleh nilai-nilai profesional, yaitu nilai intelektual, komitmen moral terhadap diri sendiri, tanggung jawab pada profesi dan masyarakat, otonomi, pengendalian tanggung jawab dan tanggung gugat.

Sebagai pemberi asuhan keperawatan, penulis memfokuskan pada asuhan keperawatan pasien dengan gangguan persyarafan stroke iskemik, melalui aplikasi teori keperawatan Adaptasi Roy.Pasien mengalami gangguan persyarafan merupakan gangguan stimulus yang berasal dari internal dan eksternal.Stimulus yang dialami pasien menyebabkan pasien mengalami gangguan mekanisme adaptasi. Menurut Roy \& Andrews (1991, dalam Alligood \& Tomey, 2006) 
gangguan mekanisme adaptasi meliputi regulator dan kognator. Gangguan adaptasi regulator merupakan gangguan fisiologis diantaranya gangguan oksigenasi akibat interupsi aliran darah ke otak, masalah nutrisi, eliminasi, aktifitas dan istirahat, proteksi, sensori/ penginderaan, cairan dan elektrolit, fungsi persyarafan, dan fungsi endokrin. Gangguan adaptasi fisiologis berkaitan erat dengan perubahan metabolisme otak (Hickey, 2003). Gangguan adaptasi kognator berhubungan dengan kognitif-emosi yaitu persepsi pasien, proses belajar, proses mempertimbangkan, dan emosi yang merupakan proses adaptasi terhadap konsep diri, peran, dan interdependensi yang muncul setelah pasien beradaptasi secara fisiologis (Roy \& Andrews, 1991 dalam Alligood \& Tomey, 2006).

Penerapan proses asuhan keperawatan yang dilakukan penulis, bertujuan untuk mengelola stimulus yang mempengaruhi perilaku pasien dengan harapan perilaku adaptif dapat dimunculkan oleh pasien. Pengelolaan stimulus meliputi merubah, meningkatkan, menurunkan, memindahkan, atau mempertahankan stimulus itu sendiri. Merubah stimulus akan memperkuat kemampuan mekanisme koping seseorang untuk berespon secara positif dan hasilnya adalah perilaku yang adaptif. Proses kompensasi dan adaptasi sangat diperlukan untuk kelangsungan hidup pasien sebagai upaya mempertahankan fungsinya. Adaptasi tersebut dapat berupa adaptasi terhadap diri pasien sendiri (manusia), adaptasi terhadap lingkungan, adaptasi terhadap perilaku hidup sehat (kesehatan), dan adaptasi terhadap cara merawat dan memelihara kondisi sehat-sakit (keperawatan). Apabila proses adaptasi terhadap kondisi sehat-sakit dan lingkungan dapat dipenuhi oleh pasien stroke maka pasien telah berupaya meningkatkan status kesehatannya. Sebaliknya, apabila pasien tidak melakukan adaptasi terhadap kondisi sakitnya maka hal tersebut dapat menurunkan status kesehatannya, sehingga perlunya peran perawat untuk membantu proses adaptasi pada pasien.

Tujuan dari penulisan ini adalah memberikan analisis pelaksanaan penerapan model konsep dan teori adaptasi menurut Roy dalam memberikan asuhan keperawatan pada pasien dengan gangguan persyarafan terutama pasien stroke iskemik di ruang perawatan persyarafan RSUPN Dr. Cipto Mangunkusumo Jakarta.

\section{STUDI KASUS DENGAN PENERAPAN TEORI KEPERAWATAN ADAPTASI ROY PADA ASUHAN KEPERAWATAN PASIEN DENGAN STROKE ISKEMIK}

Studi kasus pada Tn. AP (52 tahun) beragama Islam, Batak/ Indonesia, PNS dinas kelautan, dan sudah menikah. Pasien dirawat dengan diagnosa medis stroke iskemik. Pasien masuk RSUPN Dr. Cipto Mangunkusumo Jakarta melalui IGD pada tanggal 2 April 2011 pukul 08.00 wib, masuk di ruang perawatan persyarafan lantai V zona A RSUPN Dr Cipto Mangunkusumo Jakarta pada tanggal 4 April 2011 pukul 09.00 dan dilakukan pengkajian pada tanggal 4 April 2011 pukul 10.30 WIB.

Penerapan teori keperawatan Adaptasi Roy dalam asuhan keperawatan melalui proses keperawatan yaitu dari pengkajian sampai dengan evaluasi. Untuk mendapatkan data yang lebih lengkap dilakukan pengkajian perilaku dan pengkajian stimulus sebagai berikut:

\section{Pengkajian Perilaku dan Pengkajian Stimulus}

\section{a. Adaptasi Fisiologis}

\section{Oksigenasi}

Pengkajian stimulus fokal pada pengkajian oksigenasi didapatkan adanya infark diperiventrikel lateralis kiri, lobus frontalis; stimulus kontekstualnya hipertensi yang tidak terkontrol sejak 2 tahun yang lalu; DM sejak tahun 2003 dan stimulus residualnya adalah kebiasaan merokok (2 bungkus per hari).

\section{Nutrisi}

Pengkajian stimulus fokal pasien mengalami hiperglikemia. Stimulus kontekstualnya adanya infark diperiventrikel lateralis kiri, lobus frontalis. Sedangkan stimulus residualnya hipertensi yang tidak terkontrol sejak 2 tahun yang lalu; DM sejak tahun 2003 dan kebiasaan merokok (2 bungkus per hari).

\section{Eliminasi}

Eliminasi urin: tidak terpasang kateter. Warna urin kuning, kejernihan jernih (tidak keruh) jumlah $1500 \mathrm{cc} / \mathrm{hari}$. Eliminasi fekal: BAB $(+)$, tidak teraba masa diabdomen kiri bawah.Data di atas adalah data adaptif sehingga pengkajian stimulus tidak dilakukan.

\section{Aktifitas dan Istirahat}

Pengkajian stimulus fokal pada aktivitas didapatkan pasien mengalami hemiparese dextra dengan kekuatan otot $\frac{2222}{2222} \mid \frac{5555}{5555}$, Stimulus kontekstualnya adanya infark diperiventrikel lateralis kiri, lobus frontalis. Sedangkan stimulus residualnya hipertensi 
yang tidak terkontrol sejak 2 tahun yang lalu; DM sejak tahun 2003 dan kebiasaan merokok (2 bungkus per hari).

\section{Proteksi}

Kulit bersih, tidak ada lecet, dan edema (-). Rambut bersih, beruban, tipis dan tidak mudah rontok. Tidak terjadi penurunan imun. Survei dengan menggunakan Braden Scale maupun Norton Scale pasien tidak berisiko mengalami luka tekan. Hasil pemeriksaan laboratorium lekosit hasilnya $13,0 \quad 10^{\wedge} 3 / \mathrm{ul}$ $\left(5,0-10,010^{\wedge} 3 / \mathrm{ul}\right)$. Data di atas adalah data adaptif sehingga pengkajian stimulus tidak dilakukan.

\section{Sensori/ Penginderaan}

Nervus I, pasien dapat membedakan bau minyak kayu putih dan kopi. Nervus II, tidak ada gangguan lapang pandang, visus baik. Nervus VIII, pasien dapat mendengar, pasien dapat merasakan sentuhan. Kesan terjadi parese pada nervus VII dextra. Data di atas adalah data adaptif sehingga pengkajian stimulus tidak dilakukan.

\section{Cairan dan Elektrolit}

Turgor kulit elastis, tidak ada edema, bibir dan mukosa lembab.Nutrisi per oral. IVFD 1000 cc. Hasil laboratorium: natrium 142 $\mathrm{mEq} / \mathrm{L}(132-147 \mathrm{mEq} / \mathrm{L})$; kalium 4,35 mEq/L (3.30-5.40 mEq/L); clorida $108,5 \mathrm{mEq} / \mathrm{L}$ $(94,0-111,0 \mathrm{mEq} / \mathrm{L}) ;$ kreatinin darah 0,8 $\mathrm{mg} / \mathrm{dL} \quad(0,5-1.3 \mathrm{mg} / \mathrm{dL})$; ureum darah 36 $\mathrm{mg} / \mathrm{dL}(10-50 \mathrm{mg} / \mathrm{dL})$; asam urat darah 4,5 $\mathrm{mg} / \mathrm{dL} \quad(3,5-7,2 \mathrm{mg} / \mathrm{dL}) ;$ hematocrit 40,3 $\%(40,0-48,0 \%)$. Data di atas adalah data adaptif sehingga pengkajian stimulus tidak dilakukan.

\section{Persyarafan}

Kesadaran komposmentis, GCS $15\left(\mathrm{E}_{4} \mathrm{M}_{6} \mathrm{~V}_{5}\right)$, kekuatan otot $\frac{2222}{2222} \mid \frac{5555}{5555}$; reflek fisiologi: bisep, trisep, patella, tendon achiles $\frac{+2}{+2} \mid \frac{+2}{+2}$ dalam batas normal; reflek patologi:Chaddock, Gordon, Oppenheim, Schaefer (-/-). Fungsi serebelum baik. Fungsi otonom: inkontinensia uri et alvi, terpasang kateter menetap. Sensibilitas tidak terganggu. Tanda peningkatan tekanan intrakranial: nyeri kepala (+), muntah (-), papiledema (-). Tanda rangsang meningeal : Kernig (-/-), Laseque (/-), Babinski (-/-), Brudinski I \& II (-). Pemeriksaan saraf kranial Nervus VII (Fasialis), asimetri, otot wajah kanan mengalami kelemahan, pasien masih dapat mengerutkan kening dan mengangkat alis; Nervus XI (Aksesorius), kelemahan pada sisi tubuh sebelah kanan.
Pengkajian stimulus fokal didapatkan adanya infark diperiventrikel lateralis kiri, lobus frontalis; stimulus kontekstualnya hipertensi yang tidak terkontrol sejak 2 tahun yang lalu; DM sejak tahun 2003 dan stimulus residualnya adalah kebiasaan merokok (2 bungkus per hari).

\section{Endokrin}

Pasien mengalami gangguan metabolik, memiliki riwayat penyakit diabetes melitus (DM) dari tahun 2003. Hasil laboratorium glukosa darah puasa $246 \mathrm{mg} / \mathrm{dL}$ (70-110 $\mathrm{mg} / \mathrm{dL}$ ), HbA1C 8\% (4-6\%), glukosa urine $(+)$, keton urine (-). Pengkajian stimulus fokal didapatkan adanya glukosa darah meningkat $246 \mathrm{mg} / \mathrm{dL}$; stimulus kontekstualnya hipertensi yang tidak terkontrol sejak 2 tahun yang lalu; stimulus residualnya adalah kebiasaan merokok (2 bungkus per hari).

\section{b. Adaptasi Konsep Diri}

Pasien kooperatif selama menjalani perawatan. Pasien menyadari dirinya saat ini sedang sakit dan membutuhkan perawatan, pasien ingin segera sembuh dan kembali berkumpul dengan keluarga di rumah.

\section{c. Adaptasi Fungsi Peran}

Pasien saat ini masih aktif bekerja sebagai pegawai negeri sipil (PNS) dinas kelautan jakarta pusat. Peran sebagai pencari nafkah masih menjadi tanggungjawabnya. Pasien juga banyak aktif mengikuti kegiatan kemasyarakatan.

\section{d. Adaptasi Interdependensi}

Pasien mendapatkan dukungan penuh dari keluarga. Keluarga (anak dan istri) sangat memperhatikan pasien, mereka bergantian menunggu dan memenuhi kebutuhan pasien, tetapi istri pasien yang senantiasa menunggui pasien. Keluarga terlibat aktif dalam proses perawatan yang dilakukan terhadap pasien. Pasien menyadari dirinya saat ini sedang sakit dan membutuhkan perawatan, pasien ingin segera sembuh, dapat bekerja kembali dengan normal dan kembali berkumpul dengan keluarga di rumah, pasien dan keluarga sering bertanya dengan keadaan penyakitnya, bertanya tentang bagaimana pengobatan dan perawatannya. Pengkajian stimulus fokalnya pasien dan keluarganya tidak pernah terpapar informasi tentang pengobatan dan perawatan stroke; stimulus kontekstual sakit strokenya berasal dari hipertensi dan DM yang tidak terkontrol, stimulus residual riwayat merokok dan tidak mengetahui informasi tentang penyakitnya. 


\section{DIAGNOSA KEPERAWATAN}

Berdasarkan hasil pengkajian mode adaptif terdapat perilaku pasien yang bersifat inefektif, diantaranya adalah:

a. Gangguan perfusi jaringan serebral berhubungan dengan interupsi aliran darah serebral; infark diperiventrikel lateralis kiri, lobus frontalis.

b. Gangguan mobilisasi fisik berhubungan dengan defisit persyarafan, penurunan kekuatan otot.

c. Defisit perawatan diri berhubungan dengan : kerusakan muskuloskeletal, kerusakan neuromuskular, hemiparese.

d. Ketidakseimbangan nutrisi kurang dari kebutuhan tubuh berhubungan dengan : ketidakmampuan tubuh untuk memasukkan glukosa kedalam sel oleh karena faktor hiperglikemia.

\section{RENCANA KEPERAWATAN, IMPLEMENTASI, DANEVALUASI}

Gangguan perfusi jaringan serebral berhubungan dengan interupsi aliran darah serebral; infark diperiventrikel lateralis kiri, lobus frontalis.

Intervensi keperawatan yang direncanakan pada Tn.AP adalah untuk merubah stimulus kearah prilaku adaptif perfusi serebral adekuat dengan mengarahkan pada aktifitas regulator dan kognator: aktifitas regulatornya yaitu; Monitoring persyarafan dan peningkatan perfusi jaringan serebral adalah Monitor bentuk, kesimetrisan dan reaksi pupil, Monitor tingkat, kesadaran, Monitor tingkat orientasi, Monitor recent memori, perhatian, past memori, mood, perasaan dan perilaku, Monitor kesimetrisan wajah, Monitor tanda-tanda vital, Catat keluhan sakit kepala, Monitor MAP, Posisi kepala head up 30', Monitor status respirasi (ritme, irama, kedalaman), Monitor ICP pasien dan respon persyarafan untuk memelihara aktifitas, Berikan pengobatan nyeri bila diperlukan, Monitor perubahan hasil laboratorium dalam oksigenasi dan keseimbangan asam basa, Monitor tanda kelebihan cairan, Monitor intake dan output, aktifitas kognatornya yaitu: Anjurkan pasien untuk menghindari aktifitas yang dapat meningkatkan TIK, Anjurkan pasien menghindari fleksi leher, pinggul dan lutut secara berlebihan.

Implementasi yang penulis lakukan sesuai dengan intervensi dan aktivitas keperawatan yang telah ditetapkan. Stimulus terjadinya gangguan perfusi jaringan serebral pada Tn. AP adalah adanya infark diperiventrikel lateralis kiri, lobus frontalis. Aktifitas keperawatan yang telah penulis lakukan untuk meningkatkan perfusi jaringan serebral adalah: 1) mengatur posisi kepala $30^{\circ}$;2) mengevaluasi pemberian posisi; 3) memonitor tanda-tanda vital; 4) Monitor status respirasi (ritme, irama, kedalaman); 5) memonitor efek samping obat; 6) memonitor keefektifan obat dengan memonitor tekanan darah; 7) memonitor status persyarafan; 8) memonitor MAP; 9) menganjurkan pasien untuk menghindari aktifitas yang dapat meningkatkan TIK; 10) menganjurkan menghindari fleksi kepala dengan memberi ganjal pada leher 11) memberikan therapi Simvastatin $1 \times 20 \mathrm{mg}$, Ascardia 1x80 mg, B6B12AF 2x1, Citicolin 2x500 mg, O2 2 liter/menit.

Hasil evaluasi menunjukkan tekanan darah pasien mulai hari kelima sudah menunjukkan tekanan darah yang sama saat sebelum pasien sakit yaitu $140 / 80 \mathrm{mmHg}$, pada hari ke-6 nyeri kepala tidak ada, nadi 70 kali per menit, suhu $36,4^{\circ} \mathrm{C}$, pernapasan 20 kali per menit; kesadaran komposmentis, GCS $15\left(\mathrm{E}_{4} \mathrm{M}_{6} \mathrm{~V}_{5}\right)$, MAP sejak hari pertama dirawat sudah menunjukkan hasil normal yaitu $100 \mathrm{mmHg}(70-130 \mathrm{mmHg})$, pemeriksaan laboratorium elektrolit normal yaitu natrium $142 \mathrm{mEq} / \mathrm{L}$, kalium 4,38 mEq/L, clorida $101,0 \mathrm{mEq} / \mathrm{L}$. Pasien pulang pada perawatan hari ke-8. Dari data-data tersebut dapat disimpulkan, pada hari ke-8 pasien adaptif (integrated) terhadap masalah gangguan perfusi jaringan serebral.

\section{a. Gangguan Mobilisasi Fisik Berhubungan dengan Defisit Persyarafan}

Intervensi keperawatan yang direncanakan pada Tn.AP adalah untuk merubah stimulus kearah prilaku adaptif mobilitas fisik adekuat dengan mengarahkan pada aktifitas regulator dan kognator: aktifitas regulatornya yaitu: Tempatkan pasien dalam posisi therapeutik, Rubah posisi pasien tiap 2 jam (2 jam terlentang, 2 jam miring kearah yang sehat dan 1 jam arah yang sakit), Tentukan keterbatasan gerak sendi dah pengaruh terhadap fungsi, Jelaskan kepada pasien /keluarga tentang tujuan dan rencana latihan sendi, Hindari pasien dari trauma selama latihan, Bantu pasien dalam melakukan ROM pasif dan ROM aktif, aktifitas kognatornya yaitu: Anjurkan pasien melakukan perubahan posisi sesuai kebutuhan, Anjurkan klien melakukan ROM aktif.

Stimulus yang terjadi pada Tn. AP adalah defisit persyarafan akibat adanya infark diperiventrikel lateralis kiri, lobus frontalis dengan manifestasi hemiparese dekstra. Penulis 
menentukan dan memulai langkah-langkah yang tepat sehingga dapat merubah stimulus. Aktifitas keperawatan yang dipilih dalam latihan pergerakan sendi diantaranya : 1) menentukan keterbatasan gerakan sendi dan efeknya pada fungsi tubuh; 2) berkolaborasi dengan program latihan dengan rehabilitasi medik untuk latihan pergerakan sendi; 3) menilai motivasi pasien dalam berpartisipasi latihan; 4) menjelaskan atau mengajarkan pada pasien dan keluarga tentang pentingnya latihan pergerakan sendi; 5) menentukan lokasi nyeri atau bagian tubuh yang tidak nyaman ketika latihan; 6) memposisikan pasien yang memungkinkan untuk melakukan ROM aktif/ pasif secara maksimal; 7) menjaga pasien dari trauma selama latihan; 8) mendorong pasien untuk tetap melakukan ROM pasif/ aktif minimal 2 kali sehari selama 30 menit; 9) edukasi pada pasien dan keluarga untuk tetap latihan pada saat pasien di rumah; 10) melibatkan pasien dalam menyusun jadual latihan; 11) membantu pasien untuk duduk dengan tegak, bersandar dan duduk di tepat tidur; 12) mendorong perubahan posisi mandiri; 13) menjelaskan kepada pasien dan keluarga tentang kemajuan latihan yang dicapai dan memberikan reinforcement positif pada kemajuan yang dicapai.

Sedangkan aktifitas keperawatan dari intervensi positioning adalah 1) mengkaji risiko terjadinya luka tekan dengan menggunakan Braden Scale 16 dan Norton Scale 14 (tidak resiko untuk terjadi luka tekan); 2) memberikan tempat tidur yang selalu bersih dan rapi; 3) menentukan posisi tidur yang nyaman bagi pasien, memberikan bantal pada daerah yang mengalami kelemahan, memberikan posisi mencegak eksorotasi dengan mengendorotasikan bahu maupun panggul; 4) memposisikan pasien bersandar/ duduk di tempat tidur.

Hasil evaluasi yang diperoleh setelah dilakukan intervensi keperawatan selama 7 hari menunjukkan tujuan dari masalah gangguan mobilitas fisik tercapai, yang didukung data motivasi pasien cukup tinggi untuk latihan, pasien dan keluarga berpartisipasi dalam latihan, pasien melakukan latihan dengan perawat dan/atau keluarga 4 kali sehari, hari pertama hingga ketiga pasien duduk bersandar $90^{\circ}$, hari keempat duduk berjuntai di sisi tempat tidur dengan bantuan, hari ke-7 berpindah ke kursi roda dengan bantuan, penampilan seimbang saat pasien duduk, posisi tubuh yang nyaman saat pasien duduk, peningkatan kekuatan otot dari $\frac{2222}{2222} \mid \frac{5555}{5555}$ menjadi $\frac{3333}{3333} \mid \frac{5555}{5555}$ dan tidak terjadi kekakuan sendi terutama sendi bahu,pasien dapatberpindah posisi miring kanan/kiri secara mandiri, tidak terjadi luka akibat penekanan. Dari data-data tersebut dapat disimpulkan pasien mulai adaptif (compensatory) terhadap masalah kerusakan mobilitas fisik.

\section{b. Defisit Perawatan Diri Berhubungan dengan: Kerusakan Neuromuskular, Hemiparese Dekstra}

Intervensi keperawatan yang direncanakan pada Tn.AP adalah untuk merubah stimulus kearah prilaku adaptif perawatan diri secara mandiri dengan mengarahkan pada aktifitas regulator dan kognator : aktifitas regulatornya yaitu: Monitor kemampuan klien untuk perawatan diri yang mandiri, Monitor kebutuhan klien untuk alat-alat bantu untuk kebersihan diri, berpakaian, berhias, toileting dan makan, Sediakan bantuan sampai klien mampu secara utuh untuk melakukan self-care, aktifitas kognatornya yaitu: Dorong klien untuk melakukan aktivitas sehari-hari yang normal sesuai kemampuan yang dimiliki, Dorong untuk melakukan secara mandiri, tapi beri bantuan ketika klien tidak mampu melakukannya, Ajarkan klien/ keluarga untuk mendorong kemandirian, untuk memberikan bantuan hanya jika pasien tidak mampu untuk melakukannya, Berikan aktivitas rutin sehari-hari sesuai kemampuan, Pertimbangkan usia klien jika mendorong pelaksanaan aktivitas sehari-hari.

Stimulus yang menyebabkan defisit perawatan diri adalah kerusakan neuromuskular, hemiparese dekstra. Penulis menentukan dan memulai langkah-langkah yang dapat merubah stimulus secara tepat. Aktifitas keperawatan yang penulis lakukan antara lain : 1) Memonitor kemampuan klien untuk perawatan diri yang mandiri, 2) Memonitor kebutuhan klien untuk alat-alat bantu untuk kebersihan diri, berpakaian, berhias, toileting dan makan, 3) Menyediakan bantuan sampai klien mampu secara utuh untuk melakukan self-care, 4) Mendorong klien untuk melakukan aktivitas sehari-hari yang normal sesuai kemampuan yang dimiliki, 5) Mendorong untuk melakukan secara mandiri, tapi beri bantuan ketika klien tidak mampu melakukannya, 6) Mengajarkan klien/ keluarga untuk mendorong kemandirian, untuk memberikan bantuan hanya jika pasien tidak mampu untuk melakukannya, 7) Memberikan aktivitas rutin sehari-hari sesuai kemampuan.

Hasil evaluasi yang diperoleh setelah dilakukan intervensi keperawatan menunjukkan tujuan dari masalah defisit perawatan diri tercapai, yang didukung data motivasi pasien cukup tinggi untuk melakukan ADL, keluarga berpartisipasi membantu pasien dalam memenuhi 
kebutuhan ADL nya seperti berpakaian, mandi, toileting dan makan, setelah 7 hari dilakukan perawatan kemampuan pasien melakukan perawatan diri meningkat hal ini ditunjukkan dengan penilaian nilai barthel indeks yang meningkat yaitu 16 (ketergantungan ringan). Dari data-data tersebut dapat disimpulkan pasien mulai adaptif (compensatory) terhadap masalah defisit perawatan diri.

\section{c. Ketidakseimbangan Nutrisi Kurang dari Kebutuhan Tubuh Berhubungan dengan: Ketidakmampuan Tubuh untuk Memasukkan Glukosa ke dalam Sel oleh karena Faktor Hiperglikemia}

Intervensi keperawatan yang direncanakan pada Tn.AP adalah untuk merubah stimulus kearah prilaku adaptif nutrisi adekuat dengan mengarahkan pada aktifitas regulator dan kognator: aktifitas regulatornya yaitu: Monitor adanya penurunan BB, Monitoring kadar gula darah, Monitor tanda-tanda hipo atau hiperglikemia, Monitor kekeringan, rambut kusam, total protein, $\mathrm{Hb}$ dan kadar $\mathrm{Ht}$, Monitor mual dan muntah, Monitor pucat, kemerahan, dan kekeringan jaringan konjungtiva, Monitor intake nuntrisi, Informasikan pada klien dan keluarga tentang manfaat nutrisi, Atur posisi semi fowler atau fowler tinggi selama makan, Anjurkan banyak minum, Pertahankan terapi IV line, Kolaborasi dengan ahli gizi untuk menentukan jumlah kalori dan nutrisi yang dibutuhkan pasien, Kolaborasikan pemberian obat antihiperglikemia. Aktifitas kognatornya yaitu: Informasikan pada klien dan keluarga tentang manfaat nutrisi, Informasikan pada klien dan keluarga penatalaksanaan nutrisi pada pasien DM.

Stimulus yang menyebabkan ketidakseimbangan nutrisi kurang dari kebutuhan tubuh adalah ketidakmampuan untuk memasukkan atau mencerna nutrisi oleh karena faktor hiperglikemia. Penulis menentukan dan memulai langkah-langkah yang dapat merubah stimulus secara tepat. Aktifitas keperawatan yang penulis lakukan antara lain: 1) Memonitor adanya penurunan BB, 2) Menonitor kadar gula darah harian; Gula Darah Puasa (GDP), 3) Gula Darah Post Pandrial (GDPP), 4) Memonitor tanda-tanda hipo atau hiperglikemia, 5) Memonitor kekeringan, rambut kusam, total protein, $\mathrm{Hb}$ dan kadar $\mathrm{Ht}$, 6) Memonitor adanya mual dan muntah, 7) Memonitor pucat, kemerahan, dan kekeringan jaringan konjungtiva, 8) Memonitor intake nutrisi, 9) Memberikan informasikan pada klien dan keluarga tentang manfaat nutrisi dan penatalaksanaan DM, 10)
Mengatur posisi semi fowler atau fowler tinggi selama makan, 11) Menganjurkan banyak minum 1500-2000 cc/hari, 12) Kolaborasi dengan ahli gizi untuk menentukan jumlah kalori dan nutrisi yang dibutuhkan pasien, Kolaborasi pemberia nobat anti hiperglikemia Metformin 1x500, Glibenclamide 1x1.

Hasil evaluasi yang diperoleh setelah dilakukan intervensi keperawatan menunjukkan tujuan dari masalah resiko nutrisi kurang dari kebutuhan tubuh tercapai, yang didukung data pasien dan keluarga mengerti tentang pentingnya nutrisi bagi tubuh pasien, nilai GDP dan GDPP sebelum pulang $200 \mathrm{mg} / \mathrm{dL}$ dan $210 \mathrm{mg} / \mathrm{dL}, \mathrm{BB}$ $70 \mathrm{~kg}$, pasien dan keluarga mengerti tentang diit pada pasien DM. Dari data-data tersebut dapat disimpulkan bahwa pasien adaptif (integrated) terhadap masalah resiko ketidakseimbangan nutrisi kurang dari kebutuhan tubuh.

\section{PEMBAHASAN}

Penulis melakukan pembahasan tentang pelaksanaan asuhan keperawatan pada $\mathrm{Tn}$. AP dari pengkajian sampai dengan evaluasi, pembahasan membahas hal-hal yang ditemukan saat melakukan asuhan keperawatan dan bagaimana pelaksanaan asuhan keperawatan diberikan dengan menggunakan penerapan teori adaptasi roy.

\section{a. Gangguan Perfusi Jaringan Serebral Berhubungan dengan Interupsi Aliran Darah Serebral; Infark Diperiventrikel Lateralis Kiri, Lobus Frontalis}

Gangguan perfusi jaringan serebral terjadi karena adanya stimulus infark diperiventrikel lateralis kiri, lobus frontalis, akibat adanya oklusi serebral. Bila aliran darah jaringan otak berhenti maka oksigen dan glukosa yang diperlukan untuk pembentukan ATP akan menurun, akan terjadi penurunan Na-K ATP ase, sehingga membran potensial akan menurun. $\mathrm{K}^{+}$berpindah ke ruang ekstraseluler sementara ion $\mathrm{Na}$ dan $\mathrm{Ca}$ berkumpul di dalam sel. Hal ini menyebabkan permukaan sel menjadi lebih negatif sehingga terjadi membran depolarisasi.Saat awal depolarisasi membran sel masih reversibel, tetapi bila menetap terjadi perubahan struktural ruang menyebabkan kematian jaringan otak.Keadaan ini terjadi segera apabila perfusi menurun di bawah ambang batas kematian jaringan, yaitu bila aliran darah berkurang hingga di bawah 10 ml/100 gr/menit (Japardi, 2002; Hickey, 2003). 
Akibat kekurangan oksigen terjadi asidosis yang menyebabkan gangguan fungsi enzimenzim, karena tingginya ion $\mathrm{H}$. Selanjutnya asidosis menimbulkan edema serebral yang ditandai pembengkakan sel, terutama jaringan glia, dan berakibat terhadap mikrosirkulasi.Oleh karena itu terjadi peningkatan resistensi vaskuler dan kemudian penurunan dari tekanan perfusi sehingga terjadi perluasan daerah iskemik. Komplikasi lebih lanjut dari iskemia serebral adalah edema serebral. Kejadian ini terjadi akibat peningkatan jumlah cairan dalam jaringan otak sebagai akibat pengaruh dari kerusakan lokal atau sistemis.Segera setelah terjadi iskemia timbul edema serebral sitotoksik. Akibat dari osmosis sel cairan berpindah dari ruang ekstraseluler bersama dengan kandungan makro molekulnya. Mekanisme ini diikuti dengan pompa $\mathrm{Na} / \mathrm{K}$ dalam membran sel dimana transpor $\mathrm{Na}$ dan air kembali keluar ke dalam ruang ekstraseluler.Pada keadaan iskemia, mekanisme ini terganggu dan neuron menjadi bengkak. Apabila iskemia menetap untuk waktu yang lama, menyebabkan terjadinya edema vasogenik.Edema vasogenik yang luas setelah terjadinya iskemia dapat berupa space occupying lesion (SOL) dan berdampak pada peningkatan tekanan intrakranial (Japardi, 2002; Hickey, 2003).

Peningkatan tekanan tinggi intrakranial yang menyebabkan hilangnya kemampuan untuk menjaga keseimbangan cairan di dalam otak akan menyebabkan penekanan sistem ventrikel, sehingga cairan serebrospinalis akan berkurang. Bila hal ini berlanjut, maka akan terjadi herniasi ke segala arah. Akhirnya dapat menyebabkan iskemia global dan kematian otak (Japardi, 2002).

Upaya menurunkan stimuli untuk mencapai koping yang adaptif dalam masalah gangguan perfusi jaringan serebral, yaitu posisi penopang punggung dengan elevasi kepala $30^{\circ}$. Evaluasi terhadap masalah gangguan perfusi jaringan serebral dilakukan secara non invasif dengan melihat (tekanan darah, mean tekanan darah, nadi, suhu tubuh, frekuensi pernapasan, GCS, dan pupil). Elevasi kepala berdasarkan pada respon fisiologis merupakan perubahan posisi untuk peningkatkan aliran darah ke otak dan mencegah terjadinya peningkatan tekanan intrakranial. Aktivitas keperawatan bedrest dengan elevasi kepala $30^{\circ}$, mempunyai tujuan mencegah terjadinya penurunan tekanan perfusi serebral dan mengurangi terjadinya infark serebral lanjut (Alexander, Garami, Chernyshev, \& Alexandrov, 2005).
Hasil evaluasi menunjukkan tekanan darah pasien mulai hari kelima sudah menunjukkan tekanan darah yang sama saat sebelum pasien sakit yaitu $140 / 80 \mathrm{mmHg}$, pada hari ke-6 nyeri kepala tidak ada, nadi 70 kali per menit, suhu $36,4^{\circ} \mathrm{C}$, pernapasan 20 kali per menit; kesadaran komposmentis, GCS $15\left(\mathrm{E}_{4} \mathrm{M}_{6} \mathrm{~V}_{5}\right)$, MAP sejak hari pertama dirawat sudah menunjukkan hasil normal yaitu $100 \mathrm{mmHg}(70-130 \mathrm{mmHg})$, pemeriksaan laboratorium elektrolit normal yaitu natrium $142 \mathrm{mEq} / \mathrm{L}$, kalium 4,38 mEq/L, clorida $101,0 \mathrm{mEq} / \mathrm{L}$. Pasien pulang pada perawatan hari ke-8. Dari data-data tersebut dapat disimpulkan, pada hari ke-8 pasien adaptif (integrated) terhadap masalah gangguan perfusi jaringan serebral.

\section{b. Gangguan Mobilisasi Fisik Berhubungan dengan Defisit Persyarafan \\ Gangguan mobilisasi yang terjadi} merupakan respon yang maladaptif akibat defisit persyarafan yang dialami Tn.AP dengan manifestasi klinis hemiparese dekstra. Hemiparesis kontralateral dapat terjadi apabila kapsula internal tertekan, karena terjadi persilangan serabut saraf pada traktus piramidal dari otak ke saraf tulang belakang (Harold, Adams, \& Patricks, 2008).

Implementasi yang dilakukan untuk mengubah stimulus antara lain dengan memberikan stimulus penguatan kekuatan otot dengan merangsang respon neuromuskuler melalui stimulasi proprioseptor dan ROM pasif/ aktif. Latihan ini bertujuan memfasilitasi pola gerakan sehingga mencapai functional relevant, meningkatkan kekuatan otot, menghindari spastik akibat istirahat otot yang lama, mencegah deep venous thrombosis (DVT), memperkenalkan aktifitas mobilisasi dini, mengkompensasi sisi sakit dengan menggunakan sisi sehat.

Hasil evaluasi yang diperoleh setelah dilakukan intervensi keperawatan selama 7 hari menunjukkan tujuan dari masalah gangguan mobilitas fisik tercapai, yang didukung data motivasi pasien cukup tinggi untuk latihan, pasien dan keluarga berpartisipasi dalam latihan, pasien melakukan latihan dengan perawat dan/atau keluarga 4 kali sehari, hari pertama hingga ketiga pasien duduk bersandar $90^{\circ}$, hari keempat duduk berjuntai di sisi tempat tidur dengan bantuan, hari ke-7 berpindah ke kursi roda dengan bantuan, penampilan seimbang saat pasien duduk, posisi tubuh yang nyaman saat pasien duduk, peningkatan kekuatan otot dari $\frac{2222}{2222} \mid \frac{5555}{5555}$ menjadi $\frac{3333}{3333} \mid \frac{5555}{5555}$ dan tidak terjadi kekakuan sendi terutama sendi bahu,pasien dapat berpindah posisi miring kanan/kiri secara 
mandiri, tidak terjadi luka akibat penekanan. Dari data-data tersebut dapat disimpulkan pasien mulai adaptif (compensatory) terhadap masalah kerusakan mobilitas fisik.

\section{c. Defisit Perawatan Diri Berhubungan dengan: Kerusakan Muskuloskeletal, Kerusakan Neuromuskular, Hemiparese Dekstra}

Hemiparesis (kelemahan satu sisi tubuh) dan hemiplegia (paralisis satu sisi tubuh) dapat terjadi pada wajah, lengan, kaki, atau seluruh sisi tubuh. Hemiparesis dan hemiplegia merupakan suatu bentuk defisit motorik yang dapat menyebabkan pasien mengalami penurunan mobilitas. Kondisi imobilisasi ini akan mengakibatkan pasien mengalami komplikasi dan defisit kemampuan dalam melakukan aktivitas sehari-hari (Lewis, 2007).

Implementasi yang dilakukan untuk mengubah stimulus antara lain dengan memberikan stimulus penguatan kekuatan otot dengan merangsang respon neuromuskuler melalui stimulasi proprioseptor dan ROM pasif/ aktif. Latihan ini bertujuan memfasilitasi pola gerakan sehingga mencapai functional relevant, meningkatkan kekuatan otot, memonitor kemampuan klien untuk perawatan diri yang mandiri, memonitor kebutuhan klien untuk alatalat bantu untuk kebersihan diri, berpakaian, berhias, toileting dan makan, menyediakan bantuan sampai klien mampu secara utuh untuk melakukan self-care, mendorong klien untuk melakukan aktivitas sehari-hari yang normal sesuai kemampuan yang dimiliki, mendorong untuk melakukan secara mandiri, tapi beri bantuan ketika klien tidak mampu melakukannya, mengajarkan klien/ keluarga untuk mendorong kemandirian, untuk memberikan bantuan hanya jika pasien tidak mampu untuk melakukannya.

Hasil evaluasi yang diperoleh setelah dilakukan intervensi keperawatan menunjukkan tujuan dari masalah defisit perawatan diri tercapai, yang didukung data motivasi pasien cukup tinggi untuk melakukan ADL, keluarga berpartisipasi membantu pasien dalam memenuhi kebutuhan ADL nya seperti berpakaian, mandi, toileting dan makan, setelah 7 hari dilakukan perawatan kemampuan pasien melakukan perawatan diri meningkat hal ini ditunjukkan dengan penilaian nilai barthel indeks yang meningkat yaitu 16 (ketergantungan ringan). Dari data-data tersebut dapat disimpulkan pasien mulai adaptif (compensatory) terhadap masalah defisit perawatan diri. d. Ketidakseimbangan Nutrisi Kurang dari Kebutuhan Tubuh Berhubungan dengan: Ketidakmampuan Tubuh untuk Memasukkan Glukosa ke Dalam Sel Oleh Karena Faktor Hiperglikemia

Diabetes mellitus merupakan faktor risiko stroke iskemik yang terjadi pada pembuluh darah besar.Resistensi insulin akan mempercepat kecendrungan membentuk bekuan abnormal yang akibatnya koagulasi intravaskular semakin meningkat dari Laakso (1999, dalam Price \& Wilson, 2006). Diabetes meningkatkan faktor risiko serangan stroke sebesar $300 \%$, dan menyebabkan serangan lebih parah dan meninggalkan kecacatan yang menetap. Pengendalian diabetes merupakan faktor penting untuk mengurangi faktor risiko.

Implementasi yang dilakukan untuk mengubah stimulus antara lain dengan memberikan stimulus memonitor adanya penurunan $\mathrm{BB}$, menonitor kadar gula darah harian; Gula Darah Puasa (GDP), Gula Darah Post Pandrial (GDPP), memonitor tanda-tanda hipo atau hiperglikemia, memonitor kekeringan, rambut kusam, total protein, $\mathrm{Hb}$ dan kadar $\mathrm{Ht}$, memonitor adanya mual dan muntah, memonitor pucat, kemerahan, dan kekeringan jaringan konjungtiva, memonitor intake nuntrisi, memberikan informasikan pada klien dan keluarga tentang penyakit DM, penatalaksanaan DM, dan manfaat diit pada pasien DM, mengatur posisi semi fowler atau fowler tinggi selama makan, menganjurkan banyak minum 1500-2000 cc/hari, kolaborasi dengan ahli gizi untuk menentukan jumlah kalori dan nutrisi yang dibutuhkan pasien, Kolaborasi pemberian obat anti hiperglikemia Metformin 1x500, Glibenclamide 1x1.

Hasil evaluasi yang diperoleh setelah dilakukan intervensi keperawatan menunjukkan tujuan dari masalah nutrisi kurang dari kebutuhan tubuh tercapai, yang didukung data pasien dan keluarga mengerti tentang pentingnya nutrisi bagi tubuh pasien, nilai GDP dan GDPP sebelum pulang $200 \mathrm{mg} / \mathrm{dL}$ dan $210 \mathrm{mg} / \mathrm{dL}$, BB $70 \mathrm{~kg}$, pasien dan keluarga mengerti tentang diit pada pasien DM. Dari data-data tersebut dapat disimpulkan bahwa pasien adaptif (integrated) terhadap masalah ketidakseimbangan nutrisi kurang dari kebutuhan tubuh.

\section{Analisis Penerapan Konsep Teori Adaptasi Roy Pada Asuhan Keperawatan Pasien Gangguan Persyarafan}

Pelaksanaan asuhan keperawatan pada pasien-pasien dengan gangguan persyarafan selama praktek menggunakan teori keperawatan 
adaptasi Roy, karena teori tersebut berfokus pada pengadaptasian individu terhadap stimulus yang diterimanya baik internal maupun eksternal. Pasien dengan gangguan persyarafan mengalami masalah adaptasi ketika terpapar oleh stimulus. Fokus utama teori ini adalah adaptasi biopsikososial dan holistik, dimana tujuannya adalah meningkatkan integritas dan adaptasi positif pasien. Roy memandang individu sebagai sistem adaptif. Teori Roy banyak digunakan oleh perawat rehabilitasi yang bekerja menangani pasien-pasien yang beradaptasi terhadap perubahan dan kehilangan.

Penerapan model adaptasi Roy pada 30 kasus dengan masalah persyarafan telah penulis laksanakan di ruang perawatan persyarafan lantai V RSUPN Dr Cipto Mangunkusumo Jakarta. Tiga puluh kasus tersebut terdiri dari 14 kasus stroke iskemik, 5 kasus stroke perdarahan, 8 kasus cedera kepala, 2 kasus SOL dan 1 kasus infeksi. Penulis mengkaji perubahan mode adaptif (fisiologis, peran, konsep diri dan interdependensi), mengkaji stimulus, menegakkan diagnosa keperawatan, merencanakan intervensi, melakukan implementasi dan mengevaluasi pasien.

Pada mode fisiologis, penulis melakukan pengkajian 9 fungsi fisiologis dengan menggunakan petunjuk dan format yang telah disusun. Petunjuk pelaksanaan pengkajian secara umum dilakukan pemeriksaan yang sama pada setiap pasien, sedangkan pengkajian stimulus berbeda antara pasien satu dengan lainnya. Stimulus fokal untuk pasien dengan stroke iskemik adalah adanya infark pada lokasi serebral tertentu. Empat belas pasien pasien yang penulis kelola dengan stroke iskemik mengalami infark luas di frontotemporoparietal dan basal ganglia dextra dan atropi serebri senilis; infark akut di pons sisi kiri infark lama kapsula interna dan para ventrikel lateralis kanan dan kiri; lesi infark kronis diserebrum temporoparieto oksipitalis kanan dengan minimalis dilatasi ventrikel lateral; infark luas di frontotemporoparietal dextra; lesi infark multiple pada basal ganglia kanan dan kiri dan periventrikel kanan; lesi hipodens di capsula interna kanan dan periventrikel kiri; lesi hipodens di regio temporoparietal kiri; lesi infark diparietal bilateral; infark basal ganglia kanan, periventrikel kanan, oksipital kanan, sinusitis maksilaris; infark luas di fronto temporoparietal kanan; infark lama di periventrikel lateral kiri, suspct lesi infark akut di thalamus kiri, infark kortikal ditemporal kiri, atropi serebri; infark serebri capsula interna kiri; lesi iskemik didaerah didaerah parietal; lesi iskemik hipoden di region temporoparietalis.

Stimulus fokal untuk pasien stroke perdarahan adalah adanya perdarahan di area tertentu serebral. Lima pasien stroke perdarahan yang penulis kelola memiliki stimulus fokal adanya adanya perdarahan di cerebelum kanan dan perifokal odema; perdarahan di cerebelum kiri dan perifokal odema; perdarahan di ganglia basalis kanan dan thalamus kanan; perdarahan di basal ganglia kiri, periventrikel lateral kiri dan perifokal odema; perdarahan basal ganglia kiri dan periventrikel lateralis kiri kornu posterior.

Stimulus fokal pasien cedera kepala adalah dampak langsung dari cedera kepala yang dialami. Delapan pasien cedera kepala yang penulis kelola memiliki stimulus fokal tak tampak perdarahan intra cranial, tampak diskontinuitas os orbita kiri; ICH difrontal kiri dengan SAH; EDH di regiofrontoparietotemporal dextra; lesi hiperdense cekung mengikuti kelengkungan tulang ketebalan $<1 \mathrm{~cm}$ gyrus dan sulci lebar, lesi hiperdense homogen frontal sinistra pneumosefal cisterna membrane; EDH frontal pneumochepal multiple; SAH nontraumatik perdarahan di SAH frontal; luka tusuk dibelakang kepala, terdapat rembesan darah; fr inpresi os frontal kanan, pnemoencepal dan subgleal hematoma. Stimulus fokal satu pasien infeksi (meningitis, sida) adalah adanya inflamasi pada meningen, dengan hsil CT Scan menunjukkan adanya hidrosepalus meningen, midline shift. Sedangkan stimulus fokal dua pasien SOL adalah adanya multiple abses serebri lobus parietal kanan dan frontal kiri dengan herniasi sub falcine ke kanan; Pemeriksaan MRI dengan kontras : Kesan : Tumor lobus temporo parietal kiri --- Astrocytoma grd I-II.

Pengkajian stimulus kontekstual dan residual berbeda pada masing-masing kasus. Namun dari kasus stroke baik iskemik maupun perdarahan menunjukkan stimulus kontekstual yang sama yaitu adanya riwayat hipertensi lama yang tidak terkontrol dan riwayat DM yang lama dengan stimulus residual merokok, konsumsi alkohol, konsumsi makanan tinggi lemak, dan konsumsi kopi. Pada kasus cedera kepala stimulus kontekstual adalah mekanisme terjadinya cedera yaitu kap kontra kap dengan stimulus residual konsumsi alkohol, pemakai obat-obatan terlarang dan pemakaian alat pelindung diri seperti helm pengaman yang tidak tepat. Stimulus kontekstual kasus infeksi secara khusus belum diketahui karena belum dilakukan pemeriksaan lumbal pungsi, namun berdasarkan data yang ada stimulus kontekstualnya berasal dari infeksi oportunistik sida dan stimulus 
residualnya adalah pasien menderita penyakit $\mathrm{TB}$ paru namun putus obat. Sedangkan kontekstual untuk kasus SOL riwayat hipertensi dan stimulus residualnya adalah pasien mempunyai kebiasaan merokok.

Berdasarkan dari pengkajian stimulus, penetapan diagnosa keperawatan menurut Roy juga berdasarkan pada perilaku yang tidak efektif. Perilaku tidak efektif yang dimunculkan pasien sangat spesifik untuk area tertentu, sehingga tidak dapat menggeneralisasi beberapa aspek perilaku dari masalah yang sama, misalnya gangguan perfusi jaringan serebral. Meskipun memiliki masalah yang sama namun penatalaksanaan bisa berbeda tergantung dari penyebabnya. Hal tersebut menjadi kelemahan penerapan model adaptasi Roy pada kasus kelolaan.Roy tidak membahas secara khusus gangguan perfusi jaringan serebral. Oleh karena itu, dengan tetap mengacu pendapat dari Roy \& Andrews (1991) maka penulis melakukan modifikasi penetapan diagnosa keperawatan berdasarkan NANDA dengan intervensi keperawatan mengacu pada NIC (Nursing Intervention Classification) dan NOC (Nursing Outcome Classification). Masalah keperawatan yang umum terjadi pada pasien dengan gangguan persyarafan adalah gangguan perfusi jaringan serebral dengan berbagai penyebab.Intervensi yang diberikan berfokus pada upaya peningkatan perfusi jaringan serebral.

Tujuan dari intervensi adalah untuk mengelola stimulus dengan cara menurunkan, mengubah atau meningkatkan stimulus untuk mencapai kondisi yang adaptif. Perubahan stimulus tersebut memberikan lingkungan yang dapat mendukung proses adaptasi. Hal positif dari konsep model adaptasi Roy adalah adanya target yang jelas pada setiap intervensi keperawatan yang akan diberikan pada pasien. Target ini yang akan menjadi acuan dalam evaluasi keperawatan. Adanya perilaku yang tidak efektif setelah pemberian intervensi memberikan gambaran bahwa target atau tujuan keperawatan belum tercapai.

Implementasi dilakukan dengan memilih intervensi dan aktifitas keperawatan yang sesuai dengan adaptasi pasien (Roy dan Andrew, 1991). Pasien yang penulis rawat memiliki kondisi adaptif dan maladaptif setelah penulis menurunkan, mengubah atau meningkatkan stimulus. Kondisi yang maladaptif pada pasien berhubungan dengan tingkat efektifitas mode atau kondisi umum pasien.

\section{SIMPULAN}

Penerapan teori adaptasi menurut Roy sangat tepat pada pasien dengan gangguan persyarafan karena merupakan salah satu teori yang dinamis dan berfokus pada kemampuan adaptasi pasien dan termasuk teori yang mudah diaplikasikan, dalam penerapan asuhan Keperawatan. Roy menegaskan bahwa individu adalah makhluk biopsikososial sebagai satu kesatuan utuh yang memiliki mekanisme koping terhadap perubahan lingkungan untuk mencapai kondisi adaptif. Teori adaptasi Roy memberikan gambaran filosofi yang relevan dengan kesehatan dan kualitas hidup dimana dapat mengintegrasikan antara individu dan lingkungan.

\section{DAFTAR PUSTAKA}

Aditama, T., Y. 2000. Manajemen administrasi rumah sakit. Jakarta: Penerbit UI Press.

Alexander, A.W.W., Garami, Z., Chernyshev, O.Y., \& Alexandrov, A.V. 2005. Flat Positioning Improves Blood Flow Velocity in Acute Ischemic Stroke.

Alligood, M. R., \& Tomey, A. M. 2006.Nursing theory: utilization \& application. $3^{\text {rd }}$ Edition, Missouri: Mosby.

Fisher, M. \& Bogousslavsky, J. 1999. Current review of cerebrovascular disease. Third edition. Philadelphia: Current Medicine, Inc.

Gaffar, J. 1999. Pengantar Keperawatan Profesional. Jakarta: EGC.
Harold, P., Adams, J.R., \& Patricks, L. 2008. Assessment of A Patient with Stroke : Neurological Examination and ClinicalRating Scale. Handbook of Clinical Neurology. Vol. 94 ( $3^{\text {rd }}$ series). Elseiver.

Hickey, J.V. 2003. The Cliical Practice of Neurological and Neurosurgical Nursing. $4^{\text {th }}$. Philadelphia New York: Lippincott.

Japardi, I. 2002. Patofisiologi Stroke Infark Akibat Tromboemboli. http://library.usu.ac.id/download/fk/bedahiskandar\%20japardi31.pdf

Lewis. 2007. Medical Surgical Nursing. $7^{\text {th }}$ Edition. St.Louis: Missouri.Mosby-Year Book, Inc. 
Price, S.A., \& Wilson, L.M. 2006. Patofisiologi Konsep Klinis Proses-Proses Penyakit.

Edisi 6. Jakata: EGC. 